\title{
Antitumor effects of inhibitors of nitric oxide synthase or cyclooxygenase- 2 on human KB carcinoma cells overexpressing $\mathrm{COX}-2$
}

\author{
NAO OHTSU, KAZUKI TAKAOKA, EMI SEGAWA, SUSUMU HASHITANI, \\ KAZUMA NOGUCHI, HIROMITSU KISHIMOTO and MASAHIRO URADE \\ Department of Oral and Maxillofacial Surgery, Hyogo College of Medicine, \\ 1-1, Mukogawa-cho, Nishinomiya, Hyogo 663-8501, Japan
}

Received December 11, 2009; Accepted February 25, 2010

DOI: 10.3892/or_00000825

\begin{abstract}
Inducible nitric oxide synthase (iNOS) and cyclooxygenase (COX)-2 are major inflammatory mediators. Nitric oxide (NO) produced by iNOS has been shown to have an important role in carcinogenesis. Recent studies have suggested that COX-2 expression also contributes to carcinogenesis, as well as tumor growth, invasion, and metastasis. COX-2 inhibitors such as celecoxib are widely recognized to have antitumor activity, but can cause adverse effects. We investigated possible relations between COX-2 and NO with the use of a human epidermoid carcinoma cell line, designated $\mathrm{KB}$, in which overexpression of COX-2 protein was induced by gene transfer. We also assessed the possibility of using NOS inhibitor as an antitumor drug. We isolated a COX-2 transfected clone $(\mathrm{KB} / \mathrm{COX}-2)$ and used a neomycin-transfected clone (KB/neo) as control. $\mathrm{N}^{\mathrm{G}}$-nitro-Larginine-methyl ester (L-NAME) was used as a NOS inhibitor, dihydrochloride (1400W) as an iNOS inhibitor, and celecoxib as a selective COX-2 inhibitor. All agents inhibited the cell growth of both clones to similar extents in a dosedependent manner. Prostaglandin $\mathrm{E}_{2}\left(\mathrm{PGE}_{2}\right)$ production and COX-2 expression in $\mathrm{KB} / \mathrm{COX}-2$ were inhibited not only by celecoxib, but also by L-NAME and $1400 \mathrm{~W}$. The decreases in $\mathrm{PGE}_{2}$ production and $\mathrm{COX}-2$ expression were most prominent with celecoxib and L-NAME. In vivo, L-NAME and celecoxib significantly inhibited the proliferation of $\mathrm{KB} / \mathrm{COX}$-2-xenografted tumors. Tumor weight was reduced by L-NAME (60.6\% decrease), $1400 \mathrm{~W}$ (38.0\% decrease), and celecoxib (74.5\% decrease) as compared with the control after 21 days of treatment. Immunohistochemically, xenografted tumors expressed COX-2, iNOS, and eNOS. Such expression
\end{abstract}

Correspondence to: Dr Kazuki Takaoka, Department of Oral and Maxillofacial Surgery, Hyogo College of Medicine, 1-1 Mukogawa-cho, Nishinomiya, Hyogo 663-8501, Japan E-mail:ktaka@hyo-med.ac.jp

Key words: NOS inhibitor, COX-2 inhibitor, human KB carcinoma, COX-2 overexpression was suppressed by treatment with L-NAME and celecoxib. These results suggest that L-NAME and celecoxib significantly inhibit the proliferation of murine squamous cell carcinoma in vivo. L-NAME as well as celecoxib might thus be useful for the design and development of new antitumor drugs.

\section{Introduction}

The biosynthesis and release of nitric oxide (NO) and prostaglandins (PGs) share a number of similarities. Two major forms of nitric oxide synthase (NOS) and cyclooxygenase (COX) have been identified to date. NO is a multifunctional gaseous molecule synthesized from L-arginine by NOS. There are three isoforms of NOS: neuronal NOS (nNOS), endothelial NOS (eNOS), and inducible isoform of NOS (iNOS). nNOS and eNOS are constitutively expressed and are also referred to as constitutive NOS (cNOS). In contrast, iNOS is transcriptionally regulated and induced by inflammatory cytokines, endotoxins, hypoxia, and oxidative stress $(1,2)$. iNOS produces high, sustained concentrations of $\mathrm{NO}$, whereas the other two isoforms produce low, transient concentrations of $\mathrm{NO}(3)$.

Previous studies have shown positive correlations between iNOS and poor outcomes in patients with breast cancer and melanoma $(4,5)$. These observations suggest that NO generated by iNOS has multiple physiologic and pathologic effects. It has been reported that eNOS can modulate cancer-related events, such as angiogenesis, apoptosis, the cell cycle, tumor invasion, and metastasis (6). To our knowledge, only one clinical study has examined eNOS expression in head and neck cancer (7). That study assessed the immunohistochemical expression of eNOS in patients with hyperplasia, dysplasia, and invasive cancer and reported that eNOS expression was significantly higher in cancerous and precancerous lesions than in normal oral mucosa (7).

Cyclooxygenase (COX) catalyzes the synthesis of prostaglandins (PGs) from arachidonic acid. Two isoforms of the COX enzyme exist, COX-1 and COX-2. COX-1 is expressed constitutively in many organs, including the alimentary canal, whereas COX-2 is induced by stimuli such as cytokines and growth factors and is involved in various biologic responses 
(8-11). We previously demonstrated that overexpression of COX-2 increases cell migration in vitro and augments tumorigenicity and local tumor invasion in vivo via upregulation of MMP and Rho family small GTPases and down-regulation of TIMP activities in a human KB carcinoma cell line (12).

Inflammatory processes are mediated by multiple molecular mechanisms. Two of the most prominent are the production of NO by NOS (iNOS and eNOS) and the formation of PGs by COX-2. Given the correlation between the NOS and COX pathways, we compared the antitumor effect of NOS inhibitor with that of COX-2 inhibitor against a human KB carcinoma cell line in which malignancy was increased by gene transfer of COX-2 cDNA.

\section{Materials and methods}

Cell line and cell culture. Human KB carcinoma cell line (13) derived from epidermoid carcinoma of the floor of the mouth was used in this study. KB cells were grown in Dulbecco's modified Eagle's MEM (DMEM) (Nissui Pharmaceutical Co., Tokyo, Japan) supplemented with $10 \%$ fetal bovine serum (HyClone Laboratories, Logan, UT, USA) and $4 \mathrm{mM} \mathrm{L-glutamine}$ as growth medium at $37^{\circ} \mathrm{C}$ in a $5 \%$ $\mathrm{CO}_{2}$ incubator. This cell line was routinely subcultured with a mixture of EDTA-trypsin. KB cells that minimally possessed COX-2 protein were transfected with full-length human COX-2 cDNA (14) (a gift of Dr R. Kulmacz, University of Texas Medical School, Houston, TX) and pcDNA3 containing a neomycin-resistant marker. The calcium phosphate method was used, as described previously (14). We isolated a clone that maximally expressed COX-2 (KB/COX-2) and also isolated a neomycin-transfected clone $(\mathrm{KB} / \mathrm{neo})$ as control. COX-2 protein expression by $\mathrm{KB} / \mathrm{COX}-2$ was $\sim 3$-4-fold higher than that of $\mathrm{KB} /$ neo. There was no apparent morphological difference between $\mathrm{KB} / \mathrm{COX}-2$ and $\mathrm{KB} /$ neo.

Agents. $\mathrm{N}^{\mathrm{G}}$-nitro-L-arginine-methyl ester (L-NAME), a NOS inhibitor, was purchased from Sigma-Aldrich Co. (St. Louis, MO, USA). Dihydrochloride (1400W), a selective iNOS inhibitor, was purchased from Cayman Chemical Co. (Ann Arbor, MI, USA). These agents were dissolved in PBS(-) before use. Celecoxib, a selective COX-2 inhibitor, was generously provided by Pfizer Inc. (New York, NY, USA). This agent was dissolved in dimethylsulfoxide (DMSO) (Dojindo Laboratories, Kumamoto, Japan) before use.

Cell growth assay. Cells were plated at $2.5 \times 10^{3}$ cells/well in a $100-\mu 1$ volume in $96-$ well plates and cultured in growth medium at $37^{\circ} \mathrm{C}$. Cell growth was assessed by $3(4,5-$ dimethylethiazoly 1-2-)2,5-diphonyl tetrazolium bromide (MTT) assay after 1, 3, 5, and 7 days of incubation, as described previously (15).

Effect of inhibitors on cell growth. Cells were plated at $2.5 \times 10^{3}$ cells/well in a $100-\mu 1$ volume in $96-$ well plates and cultured in growth medium at $37^{\circ} \mathrm{C}$ for $24 \mathrm{~h}$. Various concentrations of inhibitors were added to the wells, and the cells were further cultured for $72 \mathrm{~h}$. Cell growth was assessed by MTT assay.
Prostaglandin $E_{2}\left(P G E_{2}\right)$ immunoassay. Cells were plated at $2 \times 10^{4}$ cells/well in a $1-\mathrm{ml}$ volume in 24 -well plates and grown at $37^{\circ} \mathrm{C}$ for $24 \mathrm{~h}$ in growth medium. The cells were then treated with inhibitors at the $\mathrm{IC}_{50}$ concentration for $72 \mathrm{~h}$. The medium was discarded, and $1 \mathrm{ml}$ of serum-free fresh medium was added to each well. The conditioned medium was collected after $15 \mathrm{~min}$. $\mathrm{PGE}_{2}$ assay was performed according to the protocol included with the prostaglandin $E_{2}$ EIA kit (Cayman Chemical), as described previously (15).

Western blot analysis. Cells and tumor samples were lysed in a lysis buffer consisting of $\mathrm{Mg}^{2+}$ - and $\mathrm{Ca}^{2+}$-free phosphatebuffered saline (PBS), containing $20 \mathrm{mM}$ Tris-HCl, $\mathrm{pH} 8.0$, $1 \%$ NP40, $150 \mathrm{mM} \mathrm{NaCl}, 1 \mathrm{mM}$ EDTA, 10\% glycerol, $0.1 \%$ ß-mercaptoethanol, $0.5 \mathrm{mM}$ dithiothreitol, and a mixture of proteinase inhibitors consisting of $1 \mathrm{mM}$ phenylmethylsulfonyl fluoride, $10 \mu \mathrm{g} / \mathrm{ml}$ aprotinin, $5 \mu \mathrm{g} / \mathrm{ml}$ leupeptin, $5 \mathrm{mM}$ benzamidine, $1 \mu \mathrm{g} / \mathrm{ml}$ pepstatin, $2 \mu \mathrm{g} / \mathrm{ml}$ antipain hydrochloride (Boehringer, Mannheim, Germany), $50 \mu \mathrm{M}$ 4-(2aminoethyl)-benzenesulfonyl fluoride hydrochloride (Wako Pure Chemical Industries, Ltd., Osaka, Japan), 2 mM sodium orthovanadate (Sigma-Aldrich Co.), and $20 \mathrm{U} / \mathrm{ml}$ ulinastatin (Mochida Pharmaceutical, Tokyo, Japan). Lysates containing $15 \mu \mathrm{g}$ protein were electrophoresed in a 10-20\% gradient SDSPAGE mini gel (Bio-Rad, Chicago, IL, USA) and blotted onto a PVDF membrane using Multiphor II (Amersham Pharmacia Biotech, Buchinghamshire, UK) for $30 \mathrm{~min}$. The blotted membrane was blocked with $5 \%$ skim milk in $10 \mathrm{mM}$ Tris- $\mathrm{HCl}$, pH 7.2, containing $150 \mathrm{mM} \mathrm{NaCl}$ and $0.5 \%$ Tween-20 and incubated with primary antibodies (0.1-1 $\mu \mathrm{g}$ / $\mathrm{ml})$ at $4^{\circ} \mathrm{C}$ for $16 \mathrm{~h}$ as described below. The membrane was then incubated with alkaline phosphatase-conjugated secondary antibodies $(0.02 \mu \mathrm{g} / \mathrm{ml})$ for $4 \mathrm{~h}$ at room temperature as described below. The membrane was rinsed and then treated with nitroblue tetrazolium (Sigma-Aldrich Co.) and 5-bromo4-chloro-3-indolyl phosphate (Sigma-Aldrich Co.) to visualize the protein bands. The primary antibodies used were rabbit polyclonal antibody against iNOS and eNOS and goat polyclonal antibody against COX-2 (Santa Cruz Biotechnology, Santa Cruz, CA, USA). The secondary antibodies used were anti-goat, anti-rabbit, or anti-mouse IgGs conjugated with alkaline phosphatase (Santa Cruz Biotechnology). Actin was used as internal control.

In vivo tumor xenograft study. Cells $\left(10^{6}\right)$ were inoculated subcutaneously into the flanks of 5-week-old female nude mice (BALB/C nu/nu; Oriental Yeast Ltd., Osaka, Japan). Three days after KB/COX-2 xenograft implantation, when the tumor reached $\sim 3 \mathrm{~mm}$ in diameter, the mice were treated with inhibitors. The treatment schedule comprised a single injection per animal, given subcutaneously every day for 21 days. The animals received L-NAME $(20 \mathrm{mg} / \mathrm{kg}), 1400 \mathrm{~W}$ $(20 \mathrm{mg} / \mathrm{kg})$, celecoxib (20 mg/kg), or drug vehicle (PBS[-]). The relative tumor weight $(\mathrm{mg})$ was calculated by the formula $a^{2} x b / 2$, where $a$ is the tumor width in $\mathrm{mm}$ and $b$ is the tumor length in $\mathrm{mm}$, according to the method of the Battelle Columbus Laboratories (16).

Immunohistochemical study of xenografted tumors. Tissues specimens were fixed in $10 \%$ formalin, embedded in paraffin, 
(a)

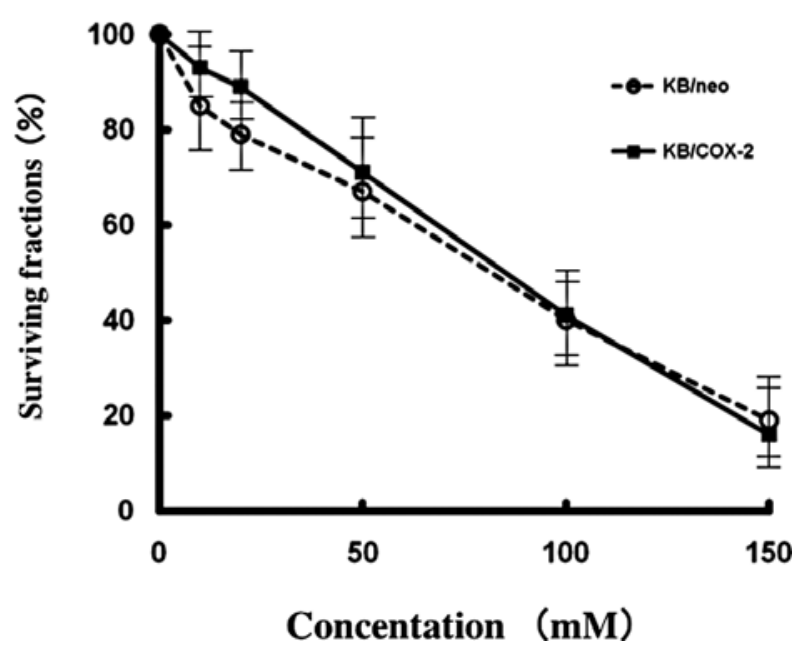

(b)

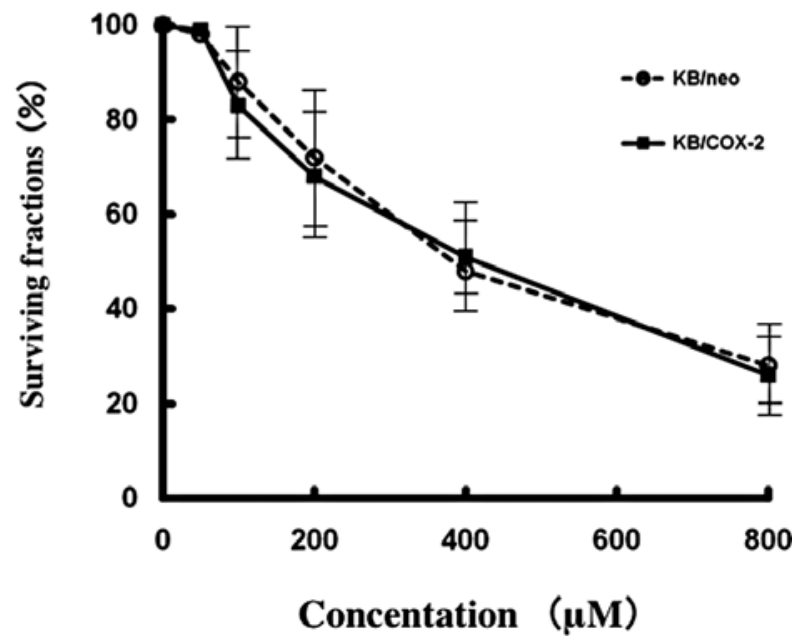

(c)

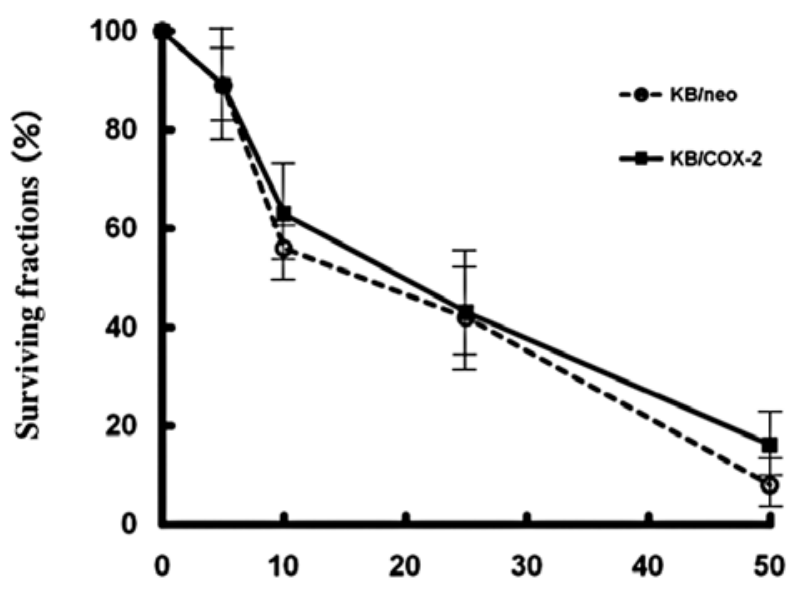

\section{Concentation $(\mu \mathrm{M})$}

Figure 1. Cell growth inhibition by the following inhibitors: (a) L-NAME, (b) $1400 \mathrm{~W}$, and (c) celecoxib in $\mathrm{KB} / \mathrm{COX}-2$ and $\mathrm{KB} /$ neo. Cell viability was determined by MTT assay after treating cells with various concentrations of inhibitors at $37^{\circ} \mathrm{C}$ for $72 \mathrm{~h} . \circ, \mathrm{KB} / \mathrm{neo}$;, $\mathrm{KB} / \mathrm{COX}-2$. Data represent the means \pm SD of 6 wells.

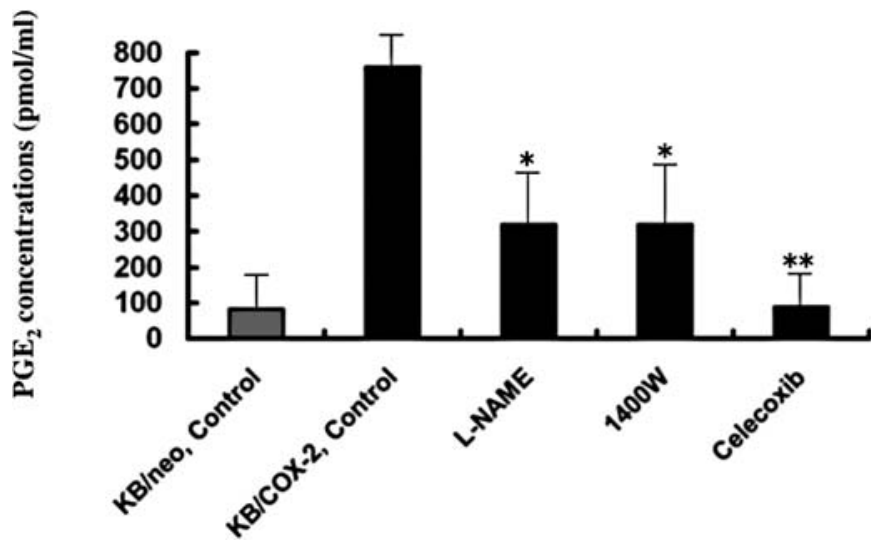

Figure 2. Effects of inhibitors on $\mathrm{PGE}_{2}$ production in $\mathrm{KB} / \mathrm{COX}-2$. Cells grown at $37^{\circ} \mathrm{C}$ for $24 \mathrm{~h}$ were treated with inhibitors at the $\mathrm{IC}_{50}$ concentration for $72 \mathrm{~h}$. Aliquots of culture medium were harvested, and $\mathrm{PGE}_{2}$ levels were determined with the use of $\mathrm{PGE}_{2}$ EIA kits. Data represent the means $\pm \mathrm{SD}$ of 6 wells. ${ }^{*} \mathrm{p}<0.05,{ }^{* *} \mathrm{p}<0.005$.

and cut into $4-\mu \mathrm{m}$ sections according to conventional procedures. Immunohistochemical examination was performed with the use of the avidin-biotin-peroxidase complex (ABC) staining method (17). Briefly, the specimens were blocked for endogenous peroxidase activity by treatment with $0.3 \%$ $\mathrm{H}_{2} \mathrm{O}_{2}$ in methanol for $5 \mathrm{~min}$. The specimens were washed and treated with $1 \%$ normal horse serum in PBS for $15 \mathrm{~min}$. After washing with PBS, rabbit polyclonal antibody for human NOS3 (Santa Cruz Biotechnology), rabbit polyclonal antibody for human NOS2 (Santa Cruz Biotechnology), or rabbit polyclonal antibody for human COX-2 (IBL, Gunma, Japan), was applied as primary antibody at $4{ }^{\circ} \mathrm{C}$ overnight. After further washing with $\mathrm{PBS}$, the specimens were incubated with ABC complex solution (Vectastain, Vector Laboratories, Burlingame, CA, USA) at room temperature for $15 \mathrm{~min}$. After washing with PBS, biotinylated goat anti-mouse IgG (Vector Laboratories) was applied to the sections, which were then incubated for $30 \mathrm{~min}$ at room temperature. The specimens were treated for $\sim 5 \mathrm{~min}$ with a substrate solution containing 3,3'-diaminobenzidine tetrahydrochloride (Wako Pure Chemical Industries, Ltd.) and $\mathrm{H}_{2} \mathrm{O}_{2}$. Finally, the specimens were counterstained with hematoxylin, dehydrated, and mounted with glycerol gelatin.

The iNOS, eNOS, and COX-2 labeling indexes (L.I.) were obtained by calculating the ratio of positive cells to the total number of tumor cells counted in well-labeled areas, as determined by scanning four areas at x200 magnification.

Statistical analysis. Statistical analysis was done with Student's $\mathrm{t}$-test. Differences were considered significant at $\mathrm{p}<0.05$.

\section{Results}

Cell growth inhibition by inhibitors. On analysis of the cell growth curves, KB/COX-2 and KB/neo showed similar growth rates. All inhibitors (L-NAME, 1400W and celecoxib) inhibited cell growth in a dose-dependent manner (Fig. 1). There was no difference between $\mathrm{KB} / \mathrm{COX}-2$ and $\mathrm{KB} /$ neo after treatment with any inhibitor. The $\mathrm{IC}_{50} \mathrm{~S}$ of L-NAME, 


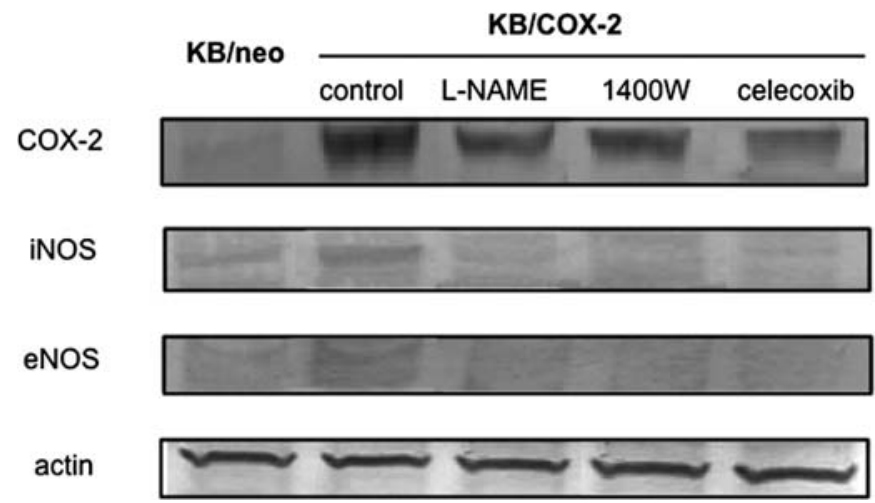

Figure 3. Expression levels of iNOS, eNOS, and COX-2 were examined by Western blot using polyclonal antibodies against these proteins. KB/COX-2 cells were grown at $37^{\circ} \mathrm{C}$ for $24 \mathrm{~h}$ and were then treated with inhibitors at the $\mathrm{IC}_{50}$ concentration for $72 \mathrm{~h}$.

$1400 \mathrm{~W}$, and celecoxib against $\mathrm{KB} / \mathrm{COX}-2$ were $85 \mathrm{mM}$, $410 \mu \mathrm{M}$, and $20 \mu \mathrm{M}$, respectively.

$P G E_{2}$ production. $\mathrm{PGE}_{2}$ production by $\mathrm{KB} / \mathrm{COX}-2$ cells was $\sim 9$ times higher than that by $\mathrm{KB} /$ neo cells. $\mathrm{PGE}_{2}$ production was inhibited by all inhibitors and was significantly inhibited by celecoxib (Fig. 2). These results suggested that not only COX-2 inhibitor but also NOS inhibitors reduced the amount of $\mathrm{PGE}_{2}$ released by $\mathrm{KB} / \mathrm{COX}-2$.

Effects of inhibitors on iNOS, eNOS, and COX-2 expression in vitro. The expression of iNOS, eNOS, and COX-2 in untreated cells was compared with that in cells treated with each inhibitor by Western blot analysis. COX-2 expression in $\mathrm{KB} / \mathrm{COX}-2$ was decreased by all inhibitors. The decreases in COX-2 expression after treatment with L-NAME and celecoxib were most prominent. However, there was no difference in the expression of iNOS or eNOS between the untreated and treated cells (Fig. 3).

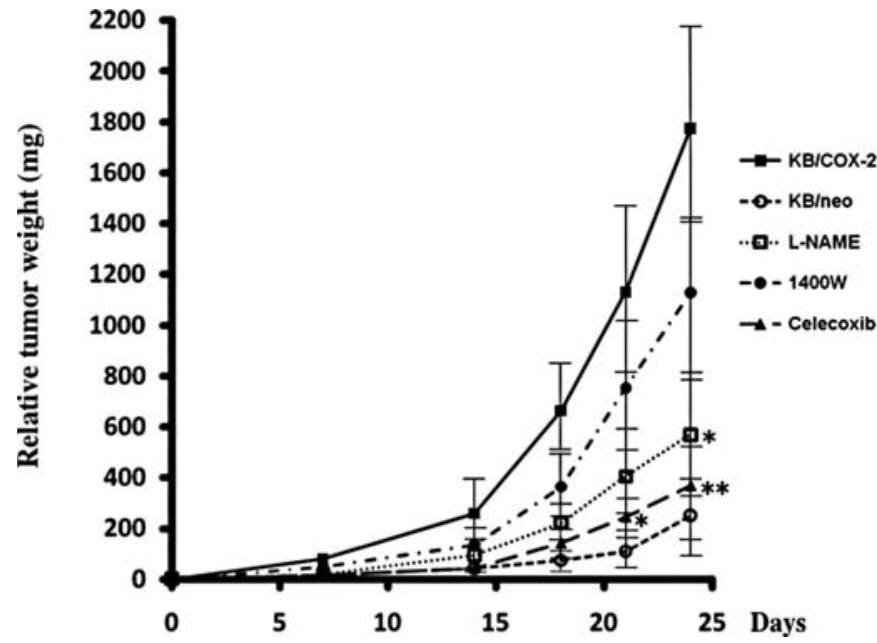

Figure 4. Effect of inhibitors on KB/COX-2 xenograft tumor volume. Cells $\left(10^{6}\right)$ were inoculated subcutaneously into the flanks of five 5-week-old female mice (BALB/C nu/nu). Beginning on day 3 after $\mathrm{KB} / \mathrm{COX}-2$ challenge, the mice were given daily subcutaneous injections of L-NAME (20 mg/day), 1400W (20 mg/day), or celecoxib (20 mg/day). Tumors developing at the inoculated sites were measured with calipers once a week. The relative tumor weight was determined according to the method of Battelle Columbus Laboratories (16). ○, KB/neo;, KB/COX-2; $\square$, L-NAME;



Effect of inhibitors on the growth of subcutaneously xenotransplanted tumors of $\mathrm{KB} / \mathrm{COX}-2$ in nude mice. After subcutaneous inoculation into nude mice, the growth of $\mathrm{KB} / \mathrm{COX}-2$ tumors was significantly greater than that of $\mathrm{KB} /$ neo tumors. All inhibitors were well tolerated by the mice, with no weight loss or signs of toxicity. These inhibitors inhibited the proliferation of the subcutaneously inoculated tumors. In KB/COX-2 tumor-bearing mice, treatment with L-NAME for 18 and 21 days significantly inhibited tumor growth as compared with treatment with vehicle $(\mathrm{p}<0.05)$. Eleven days after tumor-cell challenge, celecoxib decreased tumor size as compared with vehicle-treated mice $(\mathrm{p}<0.05)$.

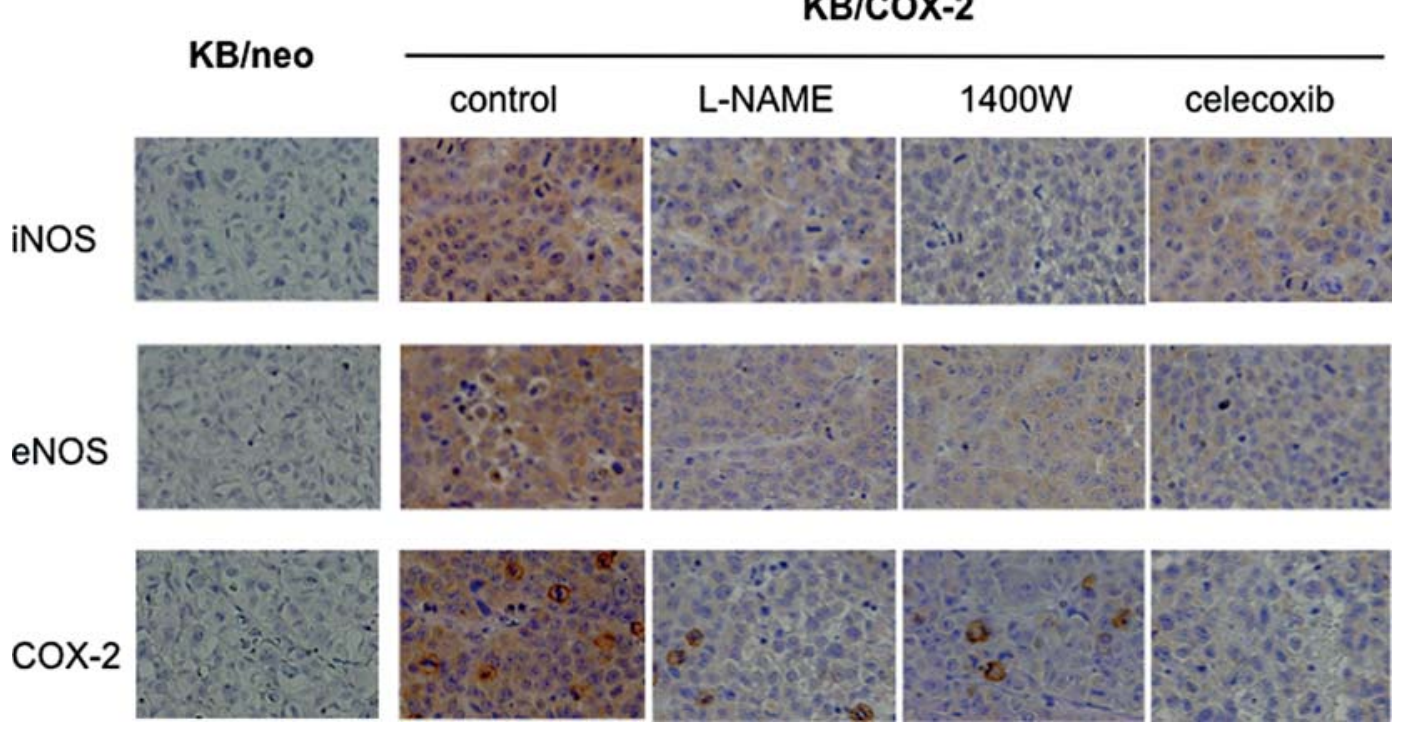

Figure 5. Immunohistochemistry of the KB/neo and KB/COX-2 tumors. KB/COX-2 tumors include tumors treated with L-NAME, $1400 \mathrm{~W}$, or celecoxib. 



Figure 6. Labeling indexes of iNOS, eNOS, and COX-2 in $\mathrm{KB} / \mathrm{COX}-2$ tumors. ${ }^{*} \mathrm{p}<0.05,{ }^{* *} \mathrm{p}<0.005,{ }^{* * *} \mathrm{p}<0.001$.

At the end of the observation period, the mean tumor volume per mouse was $570 \pm 404 \mathrm{~mm}^{3}$ (60.6\% decrease) in L-NAMEtreated mice and $369 \pm 295 \mathrm{~mm}^{3}$ (74.5\% decrease) in celecoxibtreated mice, as compared with $1448 \pm 639 \mathrm{~mm}^{3}$ in vehicletreated mice. The reduction in tumor growth did not differ significantly between L-NAME and celecoxib (Fig. 4).

Immunohistochemical evaluation. The immunoreactivity of each specimen was evaluated by light and transmission microscopy to assess the intensities of iNOS, eNOS, and COX-2 expression (Fig. 5). The iNOS L.I. was $25.5 \%$ in vehicle-treated tumors, $20.8 \%$ in L-NAME-treated tumors, $18.8 \%$ in $1400 \mathrm{~W}$-treated tumors, and $22.5 \%$ in celecoxibtreated tumors. There were no significant differences in L.I. for any of the inhibitors. The eNOS L.I. was $28.5 \%$ in vehicletreated tumors and $19 \%$ in L-NAME-treated tumors. The eNOS L.I. was significantly lower in L-NAME- and celecoxibtreated tumors than in vehicle-treated tumors. The COX-2 L.I. was $41.3 \%$ in vehicle-treated tumors, $18 \%$ in L-NAME treated tumors, $21 \%$ in $1400 \mathrm{~W}$-treated tumors, and $15.8 \%$ in celecoxib-treated tumors. The COX-2 L.I. was significantly lower in L-NAME- or celecoxib-treated tumors than in vehicle-treated tumors (Fig. 6).

\section{Discussion}

iNOS, which produces high concentrations of NO, has been shown to mediate neoplastic transformation in models of oncogene- and chemically-induced tumorigenesis, although conflicting results have been obtained (2). The effects of iNOS expression on the biologic characteristics of cancer are unclear and difficult to define; iNOS has been reported to promote as well as inhibit carcinogenesis (18). Targeting iNOS for the prevention and treatment of cancer has been extensively studied and reviewed. Ying et al (6) reported that although iNOS remains a viable candidate for cancer prevention and treatment, targeting eNOS might also be a viable strategy or least deserves attention. eNOS can regulate the expression of the proinflammatory molecules nuclear

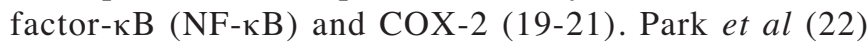
demonstrated that $\mathrm{NO}$ could increase COX-2 expression in many different cancer cell lines, including liver, cervical, and gastric cancer. They also reported that endogenous NO produced by NOS plays a key role in COX-2 expression and proposed that iNOS inhibitors could be used to regulate COX-2 expression in head and neck squamous cell carcinoma cells.

In our study, the expression of COX-2 in $\mathrm{KB} / \mathrm{COX}-2$ was decreased by NOS inhibitor treatment. The decrease was more prominent with L-NAME than with $1400 \mathrm{~W}$. Our results showed that inhibition of both iNOS and eNOS was associated with a larger decrease in COX-2 expression than that induced by iNOS inhibition alone in carcinoma cells.

Many in vivo and in vitro studies have provided evidence that COX-2 inhibitors are useful for cancer therapy, prompting various studies to investigate the structural basis underlying such activity (23). NOS inhibitors have been less extensively studied than COX-2 inhibitors for the treatment of cancer. We have shown that L-NAME, 1400W, and celecoxib reduced the rates of $\mathrm{KB} / \mathrm{COX}-2$ cell proliferation and tumor growth in mice. Treatment with L-NAME resulted in smaller tumors and lower expression of eNOS and COX-2 than did treatment with $1400 \mathrm{~W}$. Ying et al (6) reported that eNOS inhibits apoptosis and promotes angiogenesis as well as tumor cell proliferation, mobility, and invasiveness. In cell culture models, eNOS has an essential role in endothelial cell proliferation and is a central mediator of several endothelial growth stimulators, including vascular endothelial growth factor (VEGF) and $\mathrm{PGE}_{2}(24,25)$. Both molecules activate the phosphatidylinositol 3-kinase (PI3K)/Akt pathway, and VEGF increases eNOS activity by enhancing eNOS phosphorylation (6).

In addition, several studies have shown that iNOS induction in tumor cells promotes angiogenesis (by up-regulating VEGF expression), which increases microvascular density and augments tumor progression $(26,27)$. Continuous inhibition of iNOS by the selective inhibitor $1400 \mathrm{~W}$ inhibits the growth of human colon cancers as well as murine breast cancers that endogenously express iNOS. However, $1400 \mathrm{~W}$ failed to inhibit murine colon cancers that did not express iNOS at appreciable levels (28). In the present study, $1400 \mathrm{~W}$ treatment was less effective than L-NAME or celecoxib treatment for inhibiting the growth of $\mathrm{KB} / \mathrm{COX}-2$ tumors, most likely because iNOS protein expression is lower than COX-2 protein expression in this tumor model. Angiogenesis is a key step in solid tumor progression. Since eNOS has an essential role in endothelial cell proliferation, L-NAME might have led to a greater decrease in tumor weight as compared with $1400 \mathrm{~W}$ treatment 21 days after tumor cell challenge.

Overexpression of COX-2 in tumor cells affects angiogenesis by promoting the production of COX-2-derived $\mathrm{PGE}_{2}$, which stimulates endothelial cell migration and angiogenesis by increasing the expression of VEGF and augmenting the proliferation of endothelial cells $(28,29)$. Inhibition of COX-2 activity by celecoxib reduces these effects, thereby suppressing angiogenesis and decreasing tumor growth (30). Park et al (22) reported that cross-talk exists between COX and NOS in head and neck cancer cell lines. There are inter- 
actions between COX and NOS pathways among host tissues, not only in tumor tissue (31-33).

We found that NOS inhibitor blocked COX-2 expression, and COX-2 inhibitor blocked NOS (iNOS and eNOS) expression in vivo. We also showed that iNOS and eNOS levels were lower in tumors from mice treated with celecoxib in those from mice treated with L-NAME and found that celecoxib induced greater down-regulation of COX-2 than did L-NAME. Celecoxib-treated tumors were slightly smaller than L-NAME-treated tumors. However, there was no significant difference in the reduction in tumor growth between L-NAME and celecoxib. These findings suggest that the NOS inhibitor L-NAME as well as the COX-2 inhibitor celecoxib might be useful for the design and development of new antitumor drugs.

\section{Acknowledgements}

This study was supported by a Grant-in-Aid for Scientific Research from the Ministry of Education, Sports, Science and Culture of Japan to K.T. (No. 21592549) and Hyogo College of Medicine Research Funds.

\section{References}

1. Nathan C and Xie QW: Nitric oxide synthases: roles, tolls, and controls. Cell 78: 915-918, 1994.

2. Fukumura D, Kashiwagi S and Jain RK: The role of nitric oxide in tumor progression. Nat Rev Cancer 6: 521-534, 2006.

3. Beckman JS, Beckman YW, Chen J, Marshall PA and Freeman BA: Apparent hydroxyl radical production by peroxynitrite: implications for endothelial injury from nitric and superoxide. Proc Natl Acad Sci USA 87: 1620-1624, 1990.

4. Prueitt RL, Boersma BJ, Howe TM, et al: Inflammation and IGF-1 activate the Akt pathway in breast cancer. Int J Cancer 120: 796-805, 2007.

5. Ekmekcioglu S, Ellerhorst J, Prieto VG, et al: Tumor iNOS predicts poor survival for stage III melanoma patients. Int J Cancer 119: 861-866, 2006.

6. Ying L and Hofseth LJ: An emerging role for Endothelial nitric oxide synthase in chronic inflammation and cancer. Cancer Res 67: 1407-1410, 2007.

7. Bentz BG, Haines GK III, Lingen MW, Pelzer HJ, Hanson DG and Radosevich JA: Nitric oxide synthase type 3 is increased in squamous hyperplasia, dysplasia, and squamous cell carcinoma of the head and neck. Ann Otol Rhinol Laryngol 108: 781-787, 1999.

8. Vane J: Towards a better aspirin. Nature 367: 215-216, 1994.

9. Kargman SL, O'Neill GP, Vickers PJ, Evans JF, Mancini JA and Jothy S: Expression of prostaglandin G/H synthase-1 and -2 protein in human colon cancer. Cancer Res 55: 2556-2559, 1995.

10. Ristimaki A, Honkanen N, Jankala H, Sipponen P and Harkonen M: Expression of cyclooxygenase-2 in human gastric carcinoma. Cancer Res 57: 1276-1280, 1997.

11. Parrett ML, Harris R, Joarder FS, Ross MS, Clausen KP and Robertson FM: Cyclooxygenase-2 gene expression in human breast cancer. Int J Oncol 10: 503-507, 1997.

12. Takaoka K, Kishimoto H, Segawa E, et al: Elevated cell migration, invasion and tumorigenicity in human KB carcinoma cells transfected with COX-2 cDNA. Int J Oncol 29: 1095-1101, 2006.

13. Eagle $\mathrm{H}$ : Propagation in a fluid medium of a human epidermoid carcinoma, strain KB. Proc Soc Exp Biol Med 89: 362-364, 1995.
14. Kishimoto H, Wang Z, Bhat-Nakshatri P, Chang D, Clarke R and Nakshatri $\mathrm{H}$ : The p160 family coactivators regulate breast cancer cell proliferation and invasion through autocrine/paracrine activity of SDF-1 $\alpha /$ CXCL12. Carcinogenesis 26: 1706-1715, 2005.

15. Hashitani S, Urade M, Nishimura N, et al: Apoptosis induction enhancement of anticancer drugs by celecoxib, a selective cyclooxygenase- 2 inhibitor, in human head neck carcinoma cell lines. Int J Oncol 23: 665-672, 2003.

16. Ovejera AA, Houchens DP and Baker AD: Chemotherapy of human tumor xenografts in genetically athymic mice. Ann Clin Lab Sci 8: 50-56, 1978.

17. Hsu SM, Raine L and Franger H: Use of avidin-biotin-peroxidase complex $(\mathrm{ABC})$ in immunoperoxidase techniques: a comparison between $\mathrm{ABC}$ and unlabeled antibody (PAP) procedures. J Histochem Cytochem 29: 577-580, 1981.

18. Lancaster JR Jr and Xie K: Tumors face NO problems? Cancer Res 66: 6459-6462, 2006.

19. Grumbach IM, Chen W, Mertens SA and Harrison DG: A negative feedback mechanism involving nitric oxide and nuclear factor-kappaB modulates endothelial nitric oxide synthase transcription. J Mol Cell Cardiol 39: 595-603, 2005.

20. Blais V and Rivest S: Inhibitory action of nitric oxide on circulating tumor necrosis factor-induced NF-kappaB activity and COX-2 transcription in the endothelium of the brain capillaries. J Neuropathol Exp Neurol 60: 893-905, 2001.

21. Conelly L, Jacobs AT, Palacios-Callender M, Moncada S and Hobbs AJ: Macrophage endothelial nitric-oxide synthase autoregulates cellular activation and pro-inflammatory protein expression. J Biol Chem 278: 26480-26487, 2003.

22. Park SW, Lee SG, Song SH, et al: The effect of nitric oxide on cyclooxygenase-2 (COX-2) overexpression in head and neck cancer cell lines. Int J Cancer 107: 729-738, 2003.

23. Grosch S, Maier TJ, Schiffmann S and Geisslinger G: Cyclooxygenase-2 (COX-2)-independent anticarcinogenic effects of selective COX-2 inhibitors. J Natl Cancer Inst 98: 736-747, 2006.

24. Duda DG, Fukumura D and Jain RK: Role of eNOS in neovascularization: NO for endothelial progenitor cells. Trends Mol Med 10: 143-145, 2004.

25. Namkoong S, Lee SJ, Kim CK, et al: Prostaglandin E2 stimulates angiogenesis by activating the nitric oxide/cGMP pathway in human umbilical vein endothelial cells. Exp Mol Med 37: 588-600, 2005.

26. Ambs S, Bennett WP, Merrian WG, et al: p53 and vascular endothelial growth factor regulate tumor growth of NOS2expressing human carcinoma cells. Nat Med 4: 1371-1376, 1998.

27. Jenkins DC, Charles IG, Thomsen LL, et al: Roles of nitric oxide in tumor growth. Proc Natl Acad Sci USA 92: 4392-4396, 1995.

28. Li G, Yang T and Yan J: Cyclooxygenase-2 increased the angiogenic and metastatic potential of tumor cells. Biochem Biophys Res Commun 299: 886-890, 2002.

29. Liu XH, Kirschenbaum A, Yao S, et al: Upregulation of vascular endothelial growth factor by cobalt chloride-simulated hypoxia is mediated by persistent induction of cyclooxygenase-2 in a metastatic human prostate cancer cell line. Clin Exp Metastasis 17: 687-694, 1999.

30. Gately S and Li WW: Multiple roles of COX-2 in tumor angiogenesis: a target for antiangiogenic therapy. Semin Oncol 31 (2 Suppl 7): 2-11, 2004.

31. Brune B, Sandau K and von Knethen A: Apoptotic cell death and nitric oxideactivating and antagonistic transducing pathways. Biochemistry 63: 817-825, 1998.

32. Salvemini D: Regulation of cyclooxygenase enzymes by nitric oxide. Cell Mol Life Sci 53: 576-582, 1997.

33. Kanematsu M, Ikeda K and Yamada Y: Interaction between nitric oxide synthase and cyclooxygenase pathways in osteoblastic MC3T3-E1 cells. J Bone Miner Res 12: 1789-1796, 1997. 